from the level of plasma cholesterol but also from other criteria, whether butter is a 'bad' fat and safflower-seed oil a 'good' one.

\title{
REFERENCES
}

Dole, V. (1958). In Chemistry of Lipides as Related to Atherosclerosis, p. I89. [I. H. Page, editor.] Springfield, Ill.: Charles C. Thomas.

Frederickson, D. S. \& Gordon, R. S. Jt. (1958). Physiol. Rev. 38, 585.

Green, D. E. \& Gibson, D. M. (1960). In Metabolic Pathways, Vol. 1, p. 301. [D. M. Greenberg, editor.] New York and London: Academic Press Inc.

Gurd, F. R. N. (r960). In Lipide Chemistry, Chapter 9. [D. J. Hanahan, editor.] New York: John Wiley \& Sons Inc.

Hilditch, T. P. \& Jasperson, H. (1959). Lipids in Relation to Arterial Disease. Liverpool: J. Bibby \& Sons Ltd.

Kekwick, A. ( 1960$)$. Brit. med. f. ii, 407.

Korn, E. D. (1 958). In Chemistry of Lipides as Related to Atherosclerosis, p. 169. [I. H. Page, editor.] Springfield, Ill.: Charles C. Thomas.

Lehninger, A. L. (1958). In Chemistry of Lipides as Related to Atherosclerosis, p. 265. [I. H. Page, editor.] Springfield, IIl.: Charles C. Thomas.

Lynen, F. (1955). Annu. Rev. Biochem. 24, 653.

Oliver, M. F. (I961). Proc. Nutr. Soc. 20, 169.

Oncley, J. L. (1958). In Chemistry of Lipides as Related to Atherosclerosis, p. I I4. [I. H. Page, editor.] Springfield, Ill.: Charles C. Thomas.

Page, I. H. (editor) (1958). Chemistry of Lipides as Related to Atherosclerosis. Springfield, Ill.: Charles C. Thomas.

Popják, G. (editor) (1958). Metabolism of Lipids. Brit. med. Bull. 14, no. 3, pp. 197-273.

\section{The chemistry of the animal and vegetable fats in relation to their utilization and industrial processing}

\author{
By A. Crossley, Unilever Research Laboratory, Port Sunlight, Cheshire
}

In making a comparison of the chemical properties of the animal and vegetable fats it is worth first considering which fats are of the most interest in the nutritional field. Table I gives data for the most important of the fat-containing foods consumed in the United Kingdom, and Table 2 shows the proportions of animal, vegetable and marine fats. Butter, margarine, and oils and fats consumed as such, are included as

Table I. Consumption of fats in the U.K. during 1957 (derived from Devine $\&$ Williams, 196 I)

\begin{tabular}{|c|c|c|c|c|}
\hline \multirow[b]{2}{*}{ Source of fat } & \multicolumn{2}{|c|}{ Amount/head } & \multirow{2}{*}{$\begin{array}{l}\text { Percentage } \\
\text { of total }\end{array}$} & \\
\hline & $\mathrm{lb}$ & $\mathrm{kg}$ & & \\
\hline Butter & I $4 \cdot 5$ & $6 \cdot 6$ & I3 & \\
\hline Margarine & 12.9 & $5 \cdot 8$ & I I & fats \\
\hline Other animal and vegetable fats & $20 \cdot 0$ & $9 \cdot I$ & I 8 & \\
\hline Milk, cheese & 14.9 & $6 \cdot 7$ & 13 & \\
\hline Meat & $37 \cdot 6$ & $17 \cdot 1$ & 33 & \\
\hline Fish & I.9 & 0.9 & 2 & 'Invisible' \\
\hline Eggs & $3 \cdot 3$ & $1 \cdot 5$ & 3 & fats \\
\hline Cereals and nuts & $4 \cdot 7$ & 2. I & 4 & \\
\hline Cocoa products & $3 \cdot 0$ & $I \cdot 4$ & 3 & \\
\hline Total & 112.8 & $5 I \cdot 2$ & & \\
\hline
\end{tabular}


Table 2. Consumption of fats in the U.K. during 1957 (derived from Devine 8 Williams, 196r)

\begin{tabular}{lccc}
\multicolumn{1}{c}{ 'Visible' } & 'Invisible' & Total \\
Type & $(\%)$ & $(\%)$ & $(\%)$ \\
Animal & 19 & 49 & 68 \\
Marine & 4 & 2 & 6 \\
Vegetable & 19 & 7 & 26 \\
\multicolumn{1}{r}{ Total } & $\mathbf{4 2}$ & 58 &
\end{tabular}

Table 3. Consumption of fats in the U.K. from 1900 to 1957 (as percentage of total fat consumed; derived from Devine $\mathfrak{G}^{\circ}$ Williams, $\left.196 \mathrm{I}\right)$

$\begin{array}{lccccc}\quad \text { Type } & 1900 & 1924 & 1938 & 1955 & 1957 \\ \text { Animal } & 82 & 74 & 73 & 66 & 69 \\ \text { Marine } & 2 & 3 & 6 & 6 & 6 \\ \text { Vegetable } & 15 & 23 & 21 & 28 & 26 \\ \text { Hardened fat } & - & 2 & 7 & 8 & 8 \\ & & & & & \\ \text { Fat consumption: } & & & & & \\ \quad \text { lb/head } & 88 & 96 & 106 & 112 & 113 \\ \quad \text { kg/head } & 40 & 44 & 48 & 51 & 51\end{array}$

'visible' fats, whereas fat derived from, e.g., meat or eggs is regarded as 'invisible'. Table 3 shows trends in fat consumption since the year I 900 .

It is apparent that the larger proportion of the fat intake is of 'invisible' origin and that animal fats are consumed in by far the higher amount. Since r 900 there has been a gradual tendency for a reduction in the proportion of animal fats consumed and an increase in that of marine and vegetable fats. However, this trend has not been apparent recently and indeed has been reversed within the last 5 years; this type of short-term variation is almost entirely due to fluctuations in the supply of lard, which has recently been in abundant supply. It is noteworthy that the only consistent trend over the years has been the increase in total consumption of fat.

\section{The industrial processing of fats}

Visible fats form just over $40 \%$ of dietary fat. An important proportion is consumed in the form of margarine, cooking fat, or table oils, and the fats used for these products are processed commercially in order to remove objectionable odours, flavours or colours. The only fats used in large amount in the crude state are butter and lard, and the latter must be refined if it is to be used in a product such as margarine. In addition, the physical properties may have been modified by hydrogenation, or in a few instances by interesterification or by crystallization.

The refining process involves firstly a settling step to remove gums, proteins, phospholipids and other substances, which is followed by treatment with aqueous alkali to remove fatty acids. Colouring materials and other impurities are then removed by treatment with an absorbent earth at temperatures between 80 and $110^{\circ}$, 
and finally the oils are deodorized in a current of steam under highly reduced pressure for several hours to remove undesirable odours and flavours.

Various additions may be made to fats or manufactured products. Thus vitamins, salt, flavours, and colouring material are added to margarine, and synthetic antioxidants may be added to some fats. Although it has not been normal practice in the United Kingdom to add anti-oxidants, their use is becoming more widespread, particularly in the United States. The animal fats in general are lacking in natural anti-oxidants and the addition of synthetic ones does in fact give them an increased stability to oxidation.

Soft oils such as groundnut or soya-bean oils may be hydrogenated to give an increased amount of solid component, or sometimes, as with whale oil, to yield a product of improved edible quality. The process involves treatment with hydrogen at temperatures usually between $I_{5} \circ$ and $I_{8} 80^{\circ}$ in the presence of a nickel catalyst. Physical properties may also be modified by interesterification of the oil by treatment with a sodium-ethoxide catalyst at $100^{\circ}$; and also by crystallization followed by filtration, either in the presence or absence of a solvent such as acetone. Hydrogenation results in a change of the types of fatty acid present, crystallization in a change in the proportions of the fatty acids, and interesterification merely in a change in glyceride structure.

\section{Fatty-acid composition}

Detailed analyses of the fatty acids of many fats are now available in standard text books, but the features that particularly interest the nutritionist are the amounts of 'essential' fatty acids, particularly linoleic acid, the amounts of saturated acids and whether they contain appreciable amounts of short-chain acids, and also the nature of any minor component acids. In most of these characteristics the animal and the vegetable fats show a sharp contrast.

Linoleic acid is the principal 'essential' fatty acid occurring in the normal diet. However, various isomers of linoleic acid may be present. Moreover Mattson (1960) states that of the three principal isomers, i.e. the cis,cis-, cis,trans-, and the trans, trans-9, I 2-octadecadienoic acids, only the cis,cis isomer has 'essential' fatty-acid activity. Vegetable fats normally contain only the cis, cis isomer, but it is characteristic of the animal fats that all three isomers may be present. Conventional chemical methods of analysis fail to distinguish between the various isomers but recently developed techniques give more satisfactory results which correlate fairly well with biological measurements of activity. These techniques involve either selective enzymic isomerization followed by ultraviolet analysis (MacGee, Mattson \& Beck, ${ }_{195} 8$ ) or isotopic dilution with radioactive cis, cis linoleic acid followed by isolation of tetrabromides (van Beers, Sparreboom \& Keppler, 1958).

It is apparent from the above that the content of trans double bonds in fact may be of some importance, and the trans unsaturation may be measured by examination of the infrared spectrum of the methyl esters of the fatty acids. Again it is characteristic of the vegetable fats that trans double bonds are virtually absent, whereas the animal fats contain between 0 and $10 \%$. 
Table 4 gives the most important features of fatty-acid composition for a number of animal and vegetable fats.

Table 4. Fatty-acid distribution in oils and fats (compiled from several sources)

\begin{tabular}{|c|c|c|c|c|}
\hline \multirow[b]{2}{*}{ Fat } & \multirow{2}{*}{$\begin{array}{c}\text { Cis, cis linoleic } \\
\text { acid } \\
(\%)\end{array}$} & \multicolumn{2}{|c|}{ Saturated acids } & \multirow{2}{*}{$\begin{array}{c}\text { Trans } \\
\text { acids } \\
(\%)\end{array}$} \\
\hline & & $\%$ & Chain length & \\
\hline \multicolumn{5}{|l|}{ Animal: } \\
\hline Lard & $1-16^{*}$ & 50 & $\mathrm{C}_{16}-\mathrm{C}_{18}$ & $I-2$ \\
\hline Beef tallow & 2 & 55 & $\mathrm{C}_{16}-\mathrm{C}_{18}$ & $5^{-10}$ \\
\hline Butter, summer & 0.5 & 48 & $\mathrm{C}_{4}-\mathrm{C}_{18}$ & Io \\
\hline winter & 3 & 48 & $\mathrm{C}_{4}-\mathrm{C}_{18}$ & 5 \\
\hline Human depot & 4 & 36 & $\mathrm{C}_{18}-\mathrm{C}_{18}$ & 2 \\
\hline \multicolumn{5}{|l|}{ Vegetable: } \\
\hline Coconut oil & 3 & 90 & $\mathrm{C}_{8}-\mathrm{C}_{18}$ & - \\
\hline Palm oil & 10 & 48 & $\mathrm{C}_{16}-\mathrm{C}_{18}$ & - \\
\hline Olive oil & 9 & 14 & $\mathrm{C}_{18}-\mathrm{C}_{18}$ & - \\
\hline Groundnut oil & 17 & 18 & $\mathrm{C}_{16}-\mathrm{C}_{24}$ & 一 \\
\hline Cottonseed oil & 45 & 25 & $\mathrm{C}_{16}-\mathrm{C}_{18}$ & - \\
\hline Soya-bean oil & 60 & 13 & $\mathrm{C}_{16}-\mathrm{C}_{18}$ & - \\
\hline
\end{tabular}

Within recent years, and particularly since the advent of the gas-liquid chromatographic technique of analysis, it has become clear that vegetable fats contain a comparatively simple mixture of acids, whereas the animal fats contain a much larger number of acids some of which may have a rather unusual structure. Thus a fat such as palm oil contains about five component acids whereas human depot fat, which has a similar mean degree of unsaturation, contains about forty components (see Fig. I).

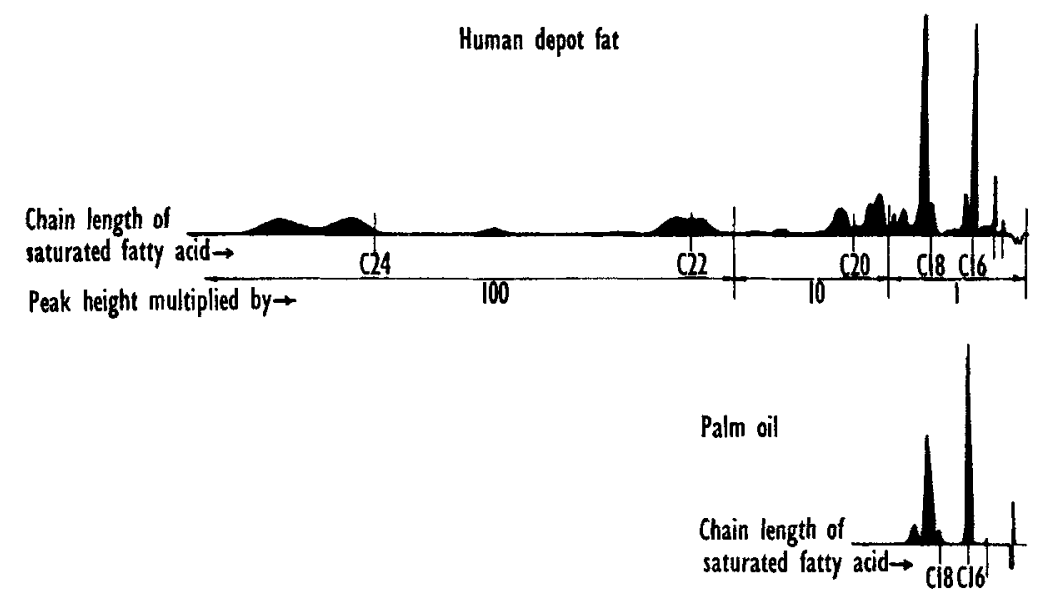

Fig. 1. Gas-liquid chromatography of fatty methyl esters with a polar stationary phase. (Unpublished work from this laboratory.)

A number of the minor component acids of animal fats are polyunsaturated but others have a branched-chain structure, have an odd number of carbon atoms, or may 
have the double bonds in positions differing from those present in the normal unsaturated acids. Hansen, Shorland \& Cooke $(1957,1959)$ have identified many of the minor components of animal fats. Thus they have isolated from butter, $\mathrm{n}$ heptadecanoic and $\mathrm{x} 4$-methylpentadecanoic acid.

Hydrogenated fats now form about $8 \%$ of the total fats consumed. Fatty-acid compositions may be considerably altered during hydrogenation with the formation of considerable quantities of trans acids and also of isomers in which migration of the double bonds has occurred. The effect of hydrogenation on methyl linoleate is shown in Table 5. The position of the double bond which was originally in the 9,10-position is found by oxidation of the hydrogenated product (Keppler, 1957); the chain length of the dibasic acid found on oxidation shows the extent of migration of this double bond during hydrogenation.

Table 5. Hydrogenation of methyl linoleate $\left(\mathrm{CH}_{3}\left(\mathrm{CH}_{2}\right)_{4} \mathrm{CH}=\mathrm{CH} \mathrm{CH}_{2} \mathrm{CH}=\mathrm{CH}\right.$ $\left(\mathrm{CH}_{2}\right)_{7} \mathrm{COOCH}_{3}$ (derived from Cousins, Guice $\&$ Feuge, 1959)

\begin{tabular}{|c|c|c|c|c|c|c|c|c|c|c|c|}
\hline \multirow{4}{*}{$\begin{array}{c}\text { Catalyst } \\
\text { None } \\
0.2 \% \mathrm{Ni}\end{array}$} & \multirow{3}{*}{$\begin{array}{l}\text { Iodine } \\
\text { value } \\
\text { of product }\end{array}$} & \multirow[b]{2}{*}{ Conditions } & \multicolumn{9}{|c|}{ Composition of dibasic acids (molar percentage) } \\
\hline & & & $\mathrm{C}_{14}$ etc. & $\mathrm{C}_{13}$ & $\mathrm{C}_{12}$ & $\mathrm{C}_{11}$ & $\mathrm{C}_{10}$ & $C_{0}$ & $\mathrm{C}_{8}$ & $\mathrm{C}_{7}$ & $\mathrm{C}_{6}$ etc \\
\hline & & & - & - & - & - & - & 95 & 5 & - & 一 \\
\hline & $90^{*}$ & $4 \mathrm{~h}$ at $110^{\circ}$ & 3 & 4 & 24 & I 6 & 14 & 29 & 7 & 3 & - \\
\hline
\end{tabular}

\section{Glyceride structure}

The main component of a fat is normally triglyceride but other glyceride types such as mono- and di-glycerides, lecithin, and sterol esters may be present in appreciable amounts. Thus crude groundnut or soya-bean oils may contain up to $5 \%$ of phosphatides which, however, would normally be removed during refining; palm oil may contain between 5 and $10 \%$ of diglycerides having the same fatty-acid composition as the oil.

It has long been realized that the structure of the glycerides in the animal and vegetable fats shows a number of characteristic differences, but it is only very recently that techniques have been devised to give a true picture of these differences. It is possible, by using pig pancreatic lipase, selectively to remove the fatty acids in the $\mathrm{I}$ - and 3-positions of a glyceride, and by analysis of the residual monoglyceride to determine the fatty groups in the 2-position. In this way a picture can be built up of the configurations of the various glycerides in the fat. Typical analyses of the mono- and di-unsaturated glycerides of four fats are given in Table 6.

Table 6. Triglyceride structure of fats (unpublished work from this laboratory)

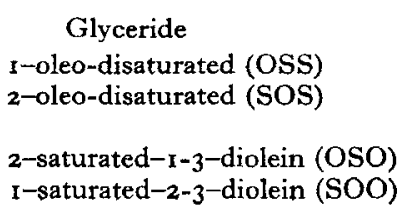

Glyceride
3-oleo-disaturated (OSS)
2-oleo-disaturated (SOS)
2-saturated-I-3-diolein (OSO)
I-saturated-2-3-diolein (SOO)

\begin{tabular}{cccc}
\multicolumn{2}{c}{ Percentage composition (based on total glycerides) } \\
\hline Lard & Beef tallow & Human depot & Cocoa butter \\
15 & 18 & 11 & Trace \\
1 & 16 & 20 & 88 \\
53 & 9 & 5 & Trace \\
7 & 32 & 39 & 10
\end{tabular}


The difference between cocoa butter and lard is particularly striking. In the mono-unsaturated glycerides of cocoa butter the unsaturated group is almost exclusively in the 2-position whereas in lard it is almost exclusively in the $\mathrm{I}$-position. It appears that with both fats the natural synthetic processes have been very selective but that the products of synthesis are entirely different. For beef tallow the glyceride structure lies somewhere between the two extremes and synthesis seems to be more random in nature. The available analytical results would suggest, in general, that in the vegetable fats an unsaturated grouping in the 2-position of the monounsaturated glycerides is favoured, with a saturated group in the I-position of the di-unsaturated glycerides; in the animal fats an unsaturated group in the I-position in the mono-unsaturated glycerides is more common, with a saturated group in the 2-position of the di-unsaturated glycerides. There seems little doubt that further analytical work on this subject will lead to a much clearer knowledge of the different synthetic processes occurring in vivo.

\section{Non-fatty components}

Non-fatty components of oils and fats represent only a small proportion of the whole; the 'unsaponifiable' component of most fats lies between 0.5 and $1.5 \%$. However, they may exhibit important biological effects and therefore may be very significant to the nutritionist. Important differences occur in the non-fatty components of animal and vegetable fats. The sterol component of animal fats is almost exclusively cholesterol, whereas in vegetable fats no cholesterol is usually found, but a mixture of 'phytosterols' occurs. The vegetable oils also contain different amounts of the various isomers of vitamin $E$ (tocopherol) whereas in most animal fats this material is almost entirely absent. Vitamin A occurs only in the animal fats but the amounts may be very small, e.g. lard contains $0.7 \mathrm{i} . \mathrm{u} . / \mathrm{g}$. However, vegetable fats may contain $\beta$-carotene, and palm oil is particularly rich in this material; it may contain as much as $\mathrm{I} \mathrm{mg} / \mathrm{g}$ in a carefully refined product. Table 7 gives the proportions of various non-fatty components in a number of animal and vegetable fats.

Table 7. Typical contents of sterols and vitamin $E$ in fats

$\begin{array}{lccc}\quad \text { Fat } & \begin{array}{c}\text { Cholesterol } \\ (\mathrm{mg} / \mathrm{I} 00 \mathrm{~g})\end{array} & \begin{array}{c}\text { Phytosterols } \\ (\mathrm{mg} / \mathrm{r} 00 \mathrm{~g})\end{array} & \begin{array}{c}\text { Vitamin E } \\ (\mathrm{mg} / \mathrm{l} 00 \mathrm{~g})\end{array} \\ \text { Beef tallow } & 75^{-140} & - & \mathrm{I} \\ \text { Lard } & 50 & - & \mathrm{I} \\ \text { Butterfat } & 240 & - & 2 \\ \text { Palm oil } & - & 30 & 50 \\ \text { Groundnut oil } & - & 200 & 50 \\ \text { Soya-bean oil } & - & 200-380 & 200\end{array}$

\section{Summary}

Although many of the major component acids of animal and vegetable fats are similar in nature, significant differences occur between the two types of fat. The fatty-acid composition of animal fats is very much more complex and a number 
of fatty acids of unusual and characteristic composition may be present. The proportion of the 'essential' cis, cis linoleic acid in the animal fats is low. Striking differences occur in glyceride composition, and lard may be regarded as the fat which differs most considerably from the vegetable type, with beef tallow or human depot fat being somewhat more random in composition. In the non-fatty components of the two groups the most significant differences arise in the sterols and vitamins. Cholesterol is the main sterol present in animal fats, whereas it is almost entirely absent in the vegetable group. Moreover, vitamin $\mathrm{E}$ is characteristic of vegetable fats and is almost entirely absent in the animal group.

These differences in composition indicate a profound difference in the in vivo synthesis of fats in the animal and vegetable species.

\section{REFERENCES}

Cousins, E. R., Guice, W. A. \& Feuge, R. O. (1959). 7. Amer. Oil Chem. Soc. 36, 24.

Devine, J. \& Williams, P. N. (editors) (1961). The Chemistry and Technology of Edible Oils and Fats. Unilever Conference. Oxford: Pergamon Press.

Hansen, R. P., Shorland, F. B. \& Cooke, N. J. (1957). Nature, Lond., 179, 98.

Hansen, R. P., Shorland, F. B. \& Cooke, N. J. (1959). Chem. E' Ind. p. I24.

Keppler, J. G. (1957). Rec. Trav. Chim. 76, 49.

MacGee, J., Mattson, F. H. \& Beck, L. W. (1958). In Essential Fatty Acids, p. 21. [H. M. Sinclair, editor.] London: Butterworths Scientific Publications.

Mattson, F. H. (1960). F. Nutr. 7r, 366.

Van Beers, G. J., Sparreboom, S. \& Keppler, J. G. (1958). In Essential Fatty Acids, p. I6. [H. M. Sinclair, editor.] London: Butterworths Scientific Publications.

\section{Animal and vegetable fats as human foods}

\section{By H. M. Sinclair, Magdalen College, Oxford}

A human food is what is ingested by man and provides one or more aliments and nutrients. A good food should not contain high concentrations of noxious substances such as carcinogens, toxins and antivitamins. The undesirability of such substances may be relative: the amounts of saturated fatty acids, cholesterol, hydroperoxides, and polymers or isomers of fatty acids may be significant in relation to the amounts of certain unsaturated fatty acids and of tocopherols. Neither processing nor additions (such as DDT) will be considered.

Fat is an obligatory dietary constituent for the supply of essential fatty acids and for no other known reason. It is a desirable dietary constituent for several reasons. First, it supplies to a person on an average mixed diet slightly less than 9 available $\mathrm{kcal} / \mathrm{g}$ whereas carbohydrate or protein supplies about $4 \mathrm{kcal}$. There are differences in animal and vegetable fats; the former supplied about $8.95 \mathrm{kcal}$ and the latter $8.35 \mathrm{kcal}$ in the diets studied by Atwater \& Bryant (1900); this was caused to a slight degree by differences in heat of combustion (animal fat, $9.40 \mathrm{kcal} / \mathrm{g}$; vegetable fat, 9.30 $\mathrm{kcal} / \mathrm{g}$ ) but to a greater extent by differences in losses in digestion (availability of animal fat, $95 \%$; of vegetable fat, $90 \%$ ). Secondly, fat is desirable for increasing the palatability of food and for decreasing hunger between meals, but there is no obvious 